\title{
UPAYA PENINGKATAN KUALITAS PELAYANAN DALAM ORGANISASI
}

\author{
Oleh Rosidah
}

rosidah@uny.ac.id

\begin{abstract}
Absrak
Seiring dengan pengembangan teknologi dan informasi, persoalan organisasi semakin bertambah banyak baik dari segi kuantitas maupun tuntutan kualitas para pengguna jasa. Macam kualitas sebagaimana tuntutan masyarakat atau pengguna jasa kantor semakin kompleks. Apalagi dengan berlakunya Undang Undang Pelayanan Publik No. 25 tahun 2009 memberikan sinyal akan perlunya organisasi memperhatikan penyelenggaraan pelayanan, karena ada kewajiban organisasi yang harus dilakukan serta pemenuhan hak pengguna jasa yang harus diperhatikan. Ini semua memaksa manajemen lembaga untuk melihat kembali sejauhmana kualitas yang dapat diberikan kepada pelanggannya. Perhatian lembaga akan kualitas pelanggan meliputi berbagai aspek. Diantaranya adalah $\mathrm{i}$ dilihat dari bagaimana membangun budaya peningkatan kualitas, memberikan kesadaran kepada sumber daya manusia organisasi akan pentingnya kualitas pelayanan. Di samping itu juga perlu perhatian terhadap aspek manajemen dalam mengaplikasikan proses penyelenggaraan pelayanan organisasi. Tidak kalah pentingnya adalah penentuan stadar kualitas pelayanan sebagai pedoman dalam penilaian kinerja.
\end{abstract}

\section{Kata kunci: kualitas pelayanan, manajemen kantor}

\section{Pendahuluan}

Kualitas pelayanan yang berstandar harus diupayakan apabila kantor ingin memberikan kepuasan yang optimal pada pengguna jasa layanan. Para pengguna jasa pelayanan, baik masyarakat maupun pihak internal organisasi mempunyai perasaan dimudahkan dan dilayani segala keperluannya. Mereka mempunyai hak untuk menerima pelayanan yang memuaskan dan sebaliknya organisasi mempunyai kewajiban untuk

menyelenggarkan pelayanan sebagaimana ketentuan Undang Undang Pelayanar Publik No. 25 tahun 2009. Undang Undang pelayanan publik merupakan upaya untuk meningkatkan kualitas dan menjamin penyediaan pelayanan publik sesuai dengan asas umum pemerintahan yang baik, serta mem berikan jaminan dan perlindungan bagi setiap warga negara dari penyalahgunaan wewenang didalam penyelenggaraan pemerintahan 
terutama yang menyąngkut bidang pelayanan publik.

Ruang lingkup pelayanan meliputi berbagai aspek, diantaranya metode, prosedur maupun sistem yang ada sebagai satu kesatuan untuk menghasilkan layanan yang memuaskan. Di sisi lain peningkatan pelayanan publik juga tidak lepas dari upaya perubahan dari SDM organisasinya, sebagaimana dikatakan John Dilulio (1994) bahwa deregulating the public service means changing personnel and procurement employes.

Sejalan

dengan

perkembangan jaman, manajer kantor dituntut untuk lebih mempunyai wawasan berpikir. secara kompleks dan komprehensip ketika akan menentukan segala kebijakan yang ada dalam kantor yang dipimpinnya. Hal tersebut mengimbangi tuntutan pérkembangan teknologi informasai dan perkembangan paradigma berpikir masyarakat sesuai dengan tingkat pengetahuan yang dimiliki. Sejauhmana tanggungjawab pimpinan akan nampak pada pola kebijakan yang dilakukan, yang dapat dirasakan oleh para bawahannya. Mengacu pada tipe kepemimpinan dalam era good governance, seperti dikatakan oleh Sartono (2004), dalam bukunya yang berjudul "Memahami Good Governance", antara lain menyebutkan bahwa kepemimpinan harus visioner dan sebagai pemberdaya, yang berimplikasi pada sifat-sifat : demokratis, delegatif, empati, tanggap, memotivasi dan menfasilitasi dan menumbuhkan situasi yang kondusif. Dengan demikian peningkatan kualitas pelayanan juga tidak lepas dari kepemimpinan sebagai pemberdaya.

\section{Membangun Kualitas Pelayanan}

Kualitas pelayanan menjadi penting artinya ketika dalam organisasi timbul permasalahan yang terkait dengan tuntutan kualitas pelayanan dari pengguna layanan. Tidak saja itu, namun semakin bertambahnya lembaga yang serupa maka adanya kompetisi dalam rangka memberikan pelayanan tersebut juga memberikan sinyal kepada lembaga untuk memperbaiki layanan kepada pihak lain. Kondisi tersebut menjadi bagian permasalahan dalam perusahaan maupun lembaga yang memperjuangkan peningkatan produk. Hal tersebut tidak saja berlaku pada perusahaan swasta akan tetapi pada era sekarang manajemen publik juga tidak lepas dari persoalan peningkatan kualitas pelayanan. Pemikiran John Dilulio (1994) bahwa the idea of deregulating the publik service needs to be studied and tested. Deregulating the public service 
while maintaining appropriate avenues of accountability is almost certain to improve the administration of the nation's federal, state and local government. Jadi sebuah kualitas pelayanan merupakan tuntutan akuntabilitas dalam sebuah lembaga.

Memulai berpikir kearah peningkatan kualitas pelayanan dan kesadaran untuk mengembangkan organisasinya melalui berbagai aspek, mulai dari perhatian terhadap kualitas produknya, kemasan, sarana dan prasarananya, kualitas sumberdaya manusianya serta akuntabilitasnya adalah sebuah perubahan yang berarati. Kesadaran tersebut harus melekat keseluruh jajaran serta telah menjadi visi organiasi. Selanjutnya visi tersebut selalu disosialisasikan, yang pada akhirnya akan menjadi budaya dalam melakukan kerja sehari-hari dan menjadi pedoman berperilaku serta pengembangan kearah peningkatan produk

Banyak faktor yang mesti diperhatikan dalam membangun kualitas pelayanan antara lain dengan menggali faktor pendorong yang menjadikan kepuasan pelanggan. Hal tersebut dapat ditelusuri melalui:

1. Kepuasan pengguna jasa atau pelanggan

Perusahaan/lembaga harus dapat mencari informasi terkait dengan apa yang menjadi harapan pelanggan yang ingin dipuaskan atau harus mengetahui persepsi pelanggan. Informasi tersebut didapatkan melalui survai pelanggan dengan membuat daftar pertanyaan yang dikirimkan/diberikan kepada pemakai jasa, yang selanjutnya jawaban pelanggan tersebut dianalisis sehinga akan memperoleh informasi yang dibutuhkan. Apabila harapan pelanggan puas kalau harapannya terhadap transaksi yang dilakukan maka mereka akan setia terhadap produk layanan kita. .

2. Dimensi kualitas produk.

Pelanggan akan merasa puas kalau setelah membeli produk baik barang atau jasa dapat memuaskan kebutuhannya. Kepuasan ini disebabkan karena produk yang telah dibeli/jasa yang telah diterima mampu memenuhi harapan. Adapun harapan pelanggan terhadap produk tersebut sangat berbeda antara pelanggan satu dengan lainnya. Hal ini disebabkan karena manusia mempunyai kebutuhan dalam kepuasan berbeda. Seseorang merasa puas dengan produk yang dibeli karena . setelah mengkonsumsi produk 
ternyata lebih şehat, setelah menggunakan produk ternyata berkualitas (tahan lama, tahan banting, tahan panas, tidak cepat rusak, dil.). Bisa jadi seseorang dengan membeli produk akan menaikkan prestisenya atau karena desainnya bagus, gambarnya bagus, dil. Ada beberapa elemen dari dimensi produk, antara lain: performance, feature, realibility.

\section{Performance}

merupakan dimensi dasar, yang berkaitan dengan fungsi utama dalam memberikan pelayanan kepada pelanggan. Konsumen akan kecewa apabila dimensi ini tidak terpenuhi. Functional value sangat melekat pada dimensi ini. Sebagai contoh: konsumen akan kecewa kalau makanan yang dibeli tidak enak dimakan, konsumen akan kecewa kalau sabun cuci yang dibeli ternyata tidak atau kurang daya pembersihnya.

Reliability, artinya
keajegan kualitas yang melekat pada produk/barang yang dibeli. Sebagai contoh kalau barang berwujud Televisi keajegan kualitas yang ditunjukkan adalah kejernihan warna yang terus menerus. Kalau baju, misalnya maka reliabilitynya berupa warna yang selalu cemerlang, tidak mudah pudar.

Feature, maksudnya beberapa tampilan tambahan terhadap produk yang ditawarkan sehingga konsumen sedikit dipuaskan.. Biasanya hal tersebut adalah sebagai faktor sekunder. Seperti adanya fasilitas tambahan untuk produk handphone dengan dapat digunakan untuk memotret, televisi ada remote controlnya.

\section{Dimensi harga}

Harga sangat berpengaruh terhadap kepuasan pelanggan.Bagi pelanggan yang sensetif terhadap harga maka harga yang murah sangat memberikan kepuasan kepadanya karena mereka akan memperoleh value for money yang tinggi. Masingmasing produk penilaian terhadap dimensi mana atau value mana yang akan menjadi titik berat dalam memuaskan pelanggan akan berbeda. Hal tersebut juga terkait dengan segmen pasar. Misalnya jika jenis barang bahan pokok, maka value yang lebih memungkinkan untuk memberikan kepuasan pelanggan adalah harga. Akan tetapi kalau jenis barang untuk kebutuhan sekunder maka 
value yanag diprioritaskan oleh penjual akan cenderung menitik beratkan kapada tahan lama ('awet'). Hal tersebut akan sangat ditentukan oleh kemauan perusahaan dalam menentukan pilihan nilai-nilai yang menjadi penekanan, sebagai salah satu keunggulan terhadap produknya.

\section{Service quality}

Dalam memberikan kepuasan pelanggan service quality menjadi faktor penting yang harus diupayakan. Meskipun dari sisi produk telah meyakinkan untuk dapat memberi kepuasan kepada pelanggan namun apabila dalam proses mendapat pelayanan dari penjual kurang baik kemungkinan yang terjadi pelanggan tidak merasa dipuaskan dengan pembelian produk/jasa yang mereka lakukan. Kepuasan terhadap kualitas pelayanan berkaitan dengan faktor sikap dan perilaku ketika melayani calon pembeli. Untuk itu maka penyelenggaraan trainingtraining terkait dengan pembentukan sikap dan perilaku perlu dilakukan oleh perusahaan.

\footnotetext{
Service quality mempunyai 5 dimensi: reliability, responsiveness, assurance, empathy, tangible. Sebuah studi yang dilakukan oleh Gronross
}

(Handi Irawan, menghasilkan bahwa ada 3 dimensi tentang kualitas, yakni: technical quality, functioal quality dan image. Technical quality adalah kualitas pelayanan yang berkaitan dengan hasil (out come) pelayanan. Konsumen puas karena hasil dari proses layanan dari penjual ketika terjadi transaksi dengan konsumen maka konsumen merasa puas.Tinjauan dari kepuasan yang dirasakan adalah konsumen merasa dipuaskan karena ternyata harga murah, produk berkualitas. Adapun tinjauan dari sisi funtional quality adalah kualitas layanan mampu memberikan kepuasan karena proses layanan yang diberikan kepada pelanggan berkualitas.

Biasanya berkaitan dengan kemampuan, ketrampilan dan keramahan yang dimiliki oleh yang memberi layanan. Tinjauan dari image walah bahwa kualitas pelayanan akan baik sangat tergantung pada image yang melekat pada produsen/produk barang/jasa. Pengaruh image ditentukan oleh opini masyarakat yang terbentuk dari berbagai aspek, misalnya saja pemakai/pengguna barang tersebut seorang terkenal atau pejabat. Hal tersebut akan menjadi preseden tersendiri 
bagi calon pembeli. Bisa jadi image tersebut dibangun oleh kultur yang berkembang di masyarakat.

\section{Emotional factor}

Kepuasan pelanggan bisa ditumbuhkan karena perusahaan mempunyai brand image yang dimiliki oleh perusahaan yang bersangkutan. Dengan brand image tersebut pelanggan yang memakai produk atau menggunakan jasa perusahaan maka secara emotional pelanggan akan merasa bangga atau dan harga dirinya lebih bisa dirasakannya sehingga mereka merasa puas. Beberapa jenis produk, misalnya saja merk baju yang terkenal, sepatu dengan merk yang terkenal, jam tangan dengan merk yang terkenal atau apa saja produk yang sudah dikenal masyarakat meskipun harganya mahal tetapi terbeli juga karena berkaitan dengan gaya hidup. Jadi masyarakat membelinya karena faktor emotional value. Perasaan bangga, harga diri, martabat bagi yang memakai produk merupakan faktor emotional yang dapat ditumbuhkan oleh perusahaaan akan barang/jasa yang ditawarkan.

Faktor mendapatkan barang/jasa
Masyarakat akan memakai atau membeli barang/jasa karena merasa lebih mudah dalam mendapatkannya. Ada beberapa

perusahaan membuka cabang-cabang di beberapa daerah untuk memudahkan konsumen membelinya atau mendapatkan apa yang dibutuhkannya., misalnya saja beberapa Bank membuka ATM dibeberapa tempat, Bank membuka cabangcabangnya dibeberapa daerah.

Dari kelima driver atau pendorong konsumen dalam menumbuhkan kepuasan pelanggan kadang berubahrubah dalam memberikan kontribusi kepada perusahaan. $\mathrm{Hal}$ ini disebabkan perkembangan selera pelanggan, perkembangan produk dan saingan atau kondisi lingkungan serta perkembangan teknologi yang terus berubah... Seberapa besar masing-masing pendorong mampu memberikan " kontribusi terhadap kepuasan pelangagan dalam pelayanan prima akan sangat berbeda. Jadi untuk memberikan kepuasan pelanggan harus selalu dilakukan evaluasi terus menerus, dengan cara survai pasar. 
Mencipatakan

Manajeman

Pelayanan

Salah satu faktor penting untuk melakukan pengembangan organisasi adalah memberikan pelayanan yang memuaskan kepada para pelanggan (customer) yang melakukan kerjasama atau membutuhkan jasa dalam hal pelayanan. Penyelenggaraan pelayanan kepada pelanggan adalah persoalan yang unik karena setiap pelanggan mempunyai karakterisstik yang berbeda dalam setiap kontak. Perbedaan ini muncul karena masing-masing pelanggan mempunyai temperamen yang berbeda. Untuk itu dibutuhkan kemampuan profesional dalam melayani berbagai tipe pelanggan.

Jasa pelayanan yang baik dan memuaskan sangat diharapkan oleh konsumen atau pelanggan. Biasanya mereka melakukan kontrol kualitas pelayanan dengan membandingkan

harapannya dengan

Pelanggan akan mempunyai kenangan atau pengalaman yang tidak dapat dihilangkan begitu saja, yang akan memberikan dampak pada siklus selanjutnya dalam proses bisnis. Salah satu cara yang mampu menetralisir kesalahan yakni dengan permohonan maaf. Untuk itu diperlukan kehati-hatian dalam memberikan pelayanan dengan berdasar pada kualitas pelayanan.

Secara definitif pelayanan mempunyai arti suatu aktivitas yang bersifat tidak kasad mata atau hanya dapat dirasakan, yang terjadi sebagai akibat adanya interaksi antara konsumen dengan karyawan atau dengan perusahaan pemberi pelayanan kepada konsumen/pelanggan. Dari tinjauan administrasi, berdasar Keputusan MENPAN No. $63 / 2003$ sebagaimana dikutip oleh Ratminto \&Atik (2005) yang dimaksud pelayanan umum adalah segala bentuk pelayanan yang dilaksanakan oleh instansi pemerintah di pusat, di daerah dan di lingkungan Badan Usaha Milik Negara atau Badan usaha Milik Daerah dalam bentuk barang dan atau jasa, baik dalam rangka upaya pemenuhan kebutuhan masyarakat maupun dalam rangka pelaksanaan ketentuan peraturan perundang-undangan. Dari kedua definisi tersebut memberikan pemahaman yang berarti bahwa dalam proses pelayanan terjadi interaksi antara dua kepentingan, yaitu pelanggan dengan lembaga baik organisasi laba (baik BUMB/BUMD maupun lembaga bisnis) maupun nirlaba (pemerintah maupun lembaga sosial). Kedua kepentingan tersebut mempunyai posisi tawar menawar, yang pada akhirnya diharapkan mampu memberikan nilai positif bagi kedua belah pihak. Dalam bargaining power tersebut pelanggan mempunyai posisi yang kuat Sehingga pelayanan yang diberikan oleh perusahaan atau organisasi bisnis harus lebih 
diperhatikan, yang pagda akhirnya juga akan memberikan dampak posistif pada pengembangan bisnisnya. Definisi pelanggan dalam hal ini tidak terbatas pada pelanggan dalam arti pembeli produk akan tetapi kualitas pelayanan merupakan siklus antara pemberi layanan dan penerima layanan. Siklus tersebut harus mampu memberikan kepuasan baik dalam bentuk phisik/non phisik dari produk yang diberikan oleh pegawai, yang dapat berupa hasil dokumen yang dibutuhkan, waktu yeng efektif maupun hubungan personal diantara kedua pihak. Sebagaimanan dikatakan di atas bahwa pelanggan bukan saja konsumen akan tetapi maknanya luas, karena dalam suatu perusahaan yang dimaksud pelanggan bisa jadi pemasok barang mentah/setengah jadi, pembeli hasil produk, para kreditur, debitur dan mereka yang melakukan transaksi bisnis dengan perusahaan.

Ada perbedaan bargaining position (tawar menawar) antara pelayanan publik "(pemerintah) dengan pelayanan yang besifat bisnis. Dalam organisasi pemerintah lebih dominan pada pejabat pemerintah yang memiliki posisi lebih tinggi dalam posisi tawar menawar. Artinya ketika seseorang membutuhkan pelayanan dengan organisasi pemerintah maka pihak pemerintah mempunyai kekuasaan lebih untuk melakukan apa saja, baik itu pelayanannya memuaskan orang yang dilayani ataukah tidak. Hal tersebut tidak/sedikit mempunyai pengaruh dengan keberadaan lembaga pemerintah. Meskipun dalam jangka panjang lembaga yang pelayanannya tidak memuaskan/optimal maka akan merugikan lembaga tersebut karena dalam perjalanannya akan bersaing dengan lembaga non pemerintah/swasta.

Sedang untuk lembaga swasta pihak pelanggan mempunyai posisi kuat karena mati hidupnya perusahaan akan sangat banyak tergantung dengan para pelanggan. Dalam organisasi yang bersifat bisnis (privat) maka kinerja pelayanan yang diselenggarakannya lebih baik karena perusahaan mempunyai ketergantungan yang kuat dengan klien (pelanggan) sehungga pelanggan mempunyai kedudukan lebih tinggi dalam bargaining posistion. . Di samping itu adanya kecenderungan kompetitif dalam kinerja pelayanan terhadiar perusahaan lain menyebabakan kedudukan pelanggan lebih kuat.

Menyikapi hal di atas maka lembaga baik pemerintah maupun swata meskipun bargaining power yang dimiliki berbeda namun tujuannya adalah sama, yakni bagaimana memberikan kepuasan kepada pelanggan sehingga 
perusahaannya/lembaganya

mampu bersaing dan survive Keduanya mempunyai tujuan yakni menaikkan income supaya lembaganya tetap menjadi pilihan.

\section{Pelayanan kepada} pelanggan dapat dikatagorikan dalam 3 jenis: 1) pelayanan barang, yakni pelayanan yang menghasilkan berbagai jenis produk barang. Contoh: perusahaan yang memproduk barang dagangan, 2). pelayanan jasa, yakni pelayanan yang menghasilkan berbagai bentuk jasa, contoh: pendidikan, jasa transportasi, 3 ). pelayanan administratif, yaitu pelayanan yang menghasilkan dokumentasi. Dari ketiga jenis pelayanan tersebut tidak lepas dari faktor manusia (sumber daya manusia) yang melakukan pelayanan artinya keberadaan manusia yang memberikan pelayanan menjadi faktor penentu terhadap kualitas pelayanan tersebut.

Ada beberapa azas dalam pelayanan yang harus dipatuhi, antara lain:

1. Bersifat terbuka (transparansi), dapat dimengerti oleh semua pihak yang membutuhkan. Dalam memberikan pelayanan maka segala aspek yang menjadi obyek pelayanan, misalnya berujud barang maka segala hal yang terkait dengan kondisi barang dapat dimintakan informasinya secara jelas kapada pemberi layanan.
2. Dapat dipertanggungjawabkan (akuntabilitas).

Berbagai bentuk layanan yang diberikan kepada pelanggan harus dapat dipertanggungjawabkan atas segala konsekuensi yang ditimbulkan akibat terjadinya transaski antara kedua belah pihak (pemberi dan penerima layanan)

3. Adanya kesamaan hak kepada pengguna layanan. Tidak menciptakan perbedaan pelayanan (diskriminatif) terhadap pihak yang dilayani, misalnya saja adanya perbedaan ras/suku, agama, jenis kelamin.

4. Adanya keseimbangan hak dan kewajiban antara pemberi dan penerima pelayanan. Kedua belah pihak harus menempatkan pada kedudukannya bahwa hak-hak yang seharusnya diberikan dengan kewajiban yang ditunaik $\sim$ proporsional.

Dalam keputusan MENPAN No. 63 th. 2003 tersebut disebutkan pula bahwa prinsip-prinsip pelayanan publik meliputi: a) kesederhanaan, b) kejelasan, c)kepastian waktu, d) akurasi, e) keamanan, f) tanggung jawab), g) kelengkapan sarana dan prasarana, h) kemudahan akses, i) kedisiplinan, kesopanan dan keramahan, j) kenyamanan. Dalam transaksi bisnis kepuasan terhadap kualitas pelayanan 
kepada pelanggan tidak berbeda dari keputusan tersebut dan prinsip tersebut dapat diadobsi sebagai acuhan dalam memberikan pelayanan. Dalam transaksi antara pemberi layanan dan. penerima pelayanan dapat dijelaskan:

Kesederhanaan, artinya prosedur untuk menyelesaikan urusan tidak berbelit-belit, mudah dilaksanakan serta dipahami. Pengguna jasa layanan tidak harus bertanya-tanya terus terkait dengan metode dan prosedur. Dengan demikian mereka merasa enak dan tidak menggerutu.

Kejelasan, artinya persyaratanpersyaratan administratif yang dibutuhkan untuk proses pelayanan jelas (tidak menimbulkan persepsi yang berbeda-beda). Juga adanya kejelasan kewenangan pihak/unit yang melayaninya serta kejelasan kepada siapa, di mana, kapan agar supaya pelanggan mudah apabila terjadi keluhan/komplain.

Ketepatan waktu dalam pengurusan yang sudeh disepakati dan menjadi suatu ukuran pasti, kapan harus selesai. Sehingga pihak pelanggan dapat merencanakan tindakan selanjutnya.

Akurasi, artinya bahwa produk pelayanan diterima oleh pelanggan benar dan tepat serta sah.

Keamanan, maksudnya produk pelayanan yang mungkin bisa terdiri dari barang, dokumentasi, jasa akan diterima oleh pelanggan dengan rasa aman dan adanya kepastian hukum.

Tanggung jawab, artinya penyelenggara pelayanan (perusahaan/perorangan) bertanggungjawab atas penyelenggaraan pelayanan serta penyelesaian urusan apabila terjadi permasalahan.

Kelengkapan sarana dan prasarana yaitu ketika terjadi proses maupun prosedur pelayanan maka tersedia sarana/prasarana yang diperlukan yang mendukung lancarnya pelayanan.

Kemudahan akses. Apabila pihak yang dilayani membutuhkan data/informasi maka data tersebut mudah untuk diperoleh. Kemudahan akses untuk tempat artinya pelanggan mudah untuk mencari tempat dimana lembaga berada.

Kedisiplinan, kesopanan' dan keramahan artinya orang-orang yang berurusan dengan proses pelayanan harus mempunyai mental dan melakukan tindakan disiplin, sopan dan ramah dalam melayaninya. Disiplin dapat berarti disiplin waktu seusai yang ditentukan, disiplin tempat, dimana harus berusuan, disiplin prosedur.

Kenyamanan artinya tersedianya tempat layanan yang 
dapat memeberikan rasa nyaman kepada pelanggan. Tempat/ruang tunggu yang representatif, lingkungan yang bersih, indah dan rapi.

Masih dalam upaya peningkatan kupuasan pada pelanggan maka dalam konsep pelayanan ada dikenal mengenai standar kualitas pelayanan. Pada dasarnya penentuan standar tersebut akan sangat tergantung pada pemberi layanan untuk dapat memenuhi kepuasan pelanggan. Tentu saja berbeda antara satu dengan lainnya. Perbedaan tersebut antara lain karena: perbedaan jenis produk layanan, tingkat kesulitan, jasa pelayanan, perbedaan tempat serta fasilitas yang ada.

\section{Kesimpulan}

Upaya melakukan pengembangan organisasi harus selalu diupayakan oleh jajaran pimpinan terlepas apakah bentuk lembaganya publik maupun swasta. Salah satu dimensi yang perlu diperhatikan adalah dengan membangun kualitas pelayanan serta memperbaiki menajemen pelayanan. Membangun budaya untuk adanya kesadaran akan pentingnya kualitas pelayanan harus melekat pada seluruh sumber daya manusia yang ada dalam organisasi. Apabila prinsip-prinsip dalam membangun manajemen pelayanan serta perhatian terhadap faktor-faktor yang mempengaruhi tingkat kualitas menjadi perhatian serta diaplikasikan dalam proses pelayanan maka akan memberikan kepuasan pada pelanggan. Di samping itu penting untuk memperhatikan adanya standar kualitas pelayanan yang menjadi ukuran/patokan dalam penilaian kualitas pelayanan.

\section{Referensi:}

Ambar Teguh Sulistiyani, 2004. Memahami Good Governance. Yogyakarta: Gava Media

John Dilulio, 1994. Deregulating The Public Service.Washington, D.C: The Brookings Instirtution.

Keputusan MENPAN No. 63 th. 2003 tentang Pelayanan Publik

Ratminto \& Atik Septi Winarsih, $2005 . \quad$ Manajemen Pelayanan. Yogyakarta: Pustaka Pelajar. 